\title{
Integrated Multi-criteria Land Suitability Evaluation and Mapping for Scaling Malt Barley Varieties in Rain-Fed Production Areas of Ethiopia
}

\author{
Adamu Molla ${ }^{1}$, Demeke Nigussie ${ }^{2}$, Zewdie Bishaw $^{1}$, Wondafrash Mulugeta $^{2} \&$ Chandrashekhar Biradar $^{3}$ \\ ${ }^{1}$ International Center for Agricultural Research in the Dry Areas, Addis Ababa, Ethiopia (Currently at Debre \\ Birhan Agricultural Research Center, Debre Birhan, Ethiopia) \\ ${ }^{2}$ Ethiopian Institute of Agricultural Research, Addis Ababa, Ethiopia \\ ${ }^{3}$ International Center for Agricultural Research in the Dry Areas, Cairo, Egypt \\ Correspondence: Zewdie Bishaw, International Center of Agricultural Research in the Dry Areas, Addis Ababa, \\ Ethiopia. Tel: 251-911-225-674. E-mail: z.bishaw@cgiar.org
}

Received: July 27, 2020

doi:10.5539/jas.v12n11p123

Accepted: September 7, 2020

Online Published: October 15, 2020

URL: https://doi.org/10.5539/jas.v12n11p123

The research is financed by USAID.

\begin{abstract}
Information on variety specific land suitability analysis was not available in Ethiopia. Therefore, integrated multi-criteria land suitability analysis and mapping for contrasting malt barley varieties was carried out to identify where and how much potentially suitable land exists in the country. The main factors considered for analysis include rainfall and temperature during the growing period, length of growing period, digital elevation models, (altitude and slope data) and soil characteristics (types, $\mathrm{pH}$, depth, texture and drainage). The malt barley varieties included are late maturing Bekoji-1, EH1847 and Holker; and early maturing Grace, IBON 174/03 and Sabini. For classification of the data layers according to the degree of suitability for each variety, various reports and other relevant information were reviewed and used in defining the limits of the suitability ranges of malt barley varieties. The overall suitability was computed by multiplying the selected criteria weight by the assigned sub-criteria score and summing these values in the ArcGIS Model Builder. The analysis showing the extent and patterns of suitable land area available for the selected malt barley varieties are presented in the form of tabular data and maps. Highly suitable areas for these varieties include: 125,332 ha for Bekoji-1; 124,004 ha for EH1847; 775,312 ha for Grace; 125,356 ha for Holker; 1,677,388 ha for IBON 174/03; and 307,952 ha for Sabini. The results suggest that current improved malt barley varieties can be targeted for scaling out in the identified land suitability classes in the highlands of Ethiopia. Results also suggest that future research and development works should give priority for developing early maturing, acidic and waterlogging soil tolerant malt barley varieties. The results can be useful for policy and decision making to ensure land resources are used in the most productive and sustainable ways and solve the mismatches between current land use and land suitability for malt barley varieties in the country.
\end{abstract}

Keywords: environmental requirement, Ethiopian highlands, land suitability, malt barley, mapping

\section{Introduction}

Barley has been an important food and industrial crop in Ethiopia. Although Ethiopia is the second largest barley producer in Africa, accounting for about 25\% of the total barley production (Food and Agriculture Organization [FAO], 2014), it has not yet been able to expand malt barley production. The share of malting barley production is quite low and constitutes about 10-15\% of the total barley area of about 959,273 ha in 2016/2017 meher season (Ethiopian Institute of Agricultural Research [EIAR], 2015; Central Statistical Agency [CSA], 2017). On the other hand, the booming demand of breweries for supply of quality malt barley has been increasing in Ethiopia (Gessesse, 2017). However, due to low productivity, poor malt quality, and very limited expansion of malt barley production, the net import bill for malt barley jumped from US\$240 thousand in 1997 to US\$40 million in 2014 and is projected to reach as high as US $\$ 420$ million by 2025 (Lakew, Yigezu, Yirga, \& Aw-Hassan, 2015; Rashid, Abate, Lemma, Warner, Kasa, \& Minot, 2015). 
Abiotic and biotic stresses, weak technology generation and transfer, limited availability and access to inputs, sub-optimal application of fertilizers, and poor access to markets due to poor linkages between the farmer producers and the brewing industry are the main constraints responsible for low productivity, poor malt quality and limited expansion of malt barley production in Ethiopia. Among abiotic stresses, it is a well-established fact that the physical environment strongly affects the genetic potential and quality of malt barley (Ajith, 2009; Muhe, 2011; EIAR, 2015; Mehari, Alamerew, \& Lakew, 2015; Mekonnen, 2013; Rashid, Abate, Lemma, Warner, Kasa, \& Minot, 2015). In our study, the physical environment includes the soil type, soil depth, soil $\mathrm{pH}$, soil texture, soil drainage, land slope, altitude, length of growing period, and climate (rainfall and temperature). The interaction and/or main effects of these components of the physical environment not only determine productivity but also the very existence and distribution of plant species in Ethiopia (Boke \& Fekadu, 2019; Gashaw, Tulu, \& Argaw, 2017; Hurni, 1998; Merga \& Ahmed, 2019; MoA, 1998). Different reports showed the large contrasts in elevation and topography that characterize the country are very effective in controlling local climate conditions to such an extent that even sites within a short distance may show very different climatic conditions (Fazzini, Bisci, \& Billi, 2015; FAO, 2016; Jembere, Mamo, \& Kibret, 2017). The large elevation and topographic variability results in a wide range of temperatures that may be as low as $-7^{\circ} \mathrm{C}$ in the Bale Mountains $(4,377 \mathrm{~m}$ above sea level) and as high as $50{ }^{\circ} \mathrm{C}$ in the Danakil Depression of $115-125 \mathrm{~m}$ below sea level. Similarly, the long-term observations indicate that higher rainfalls are recorded in the western highlands, with 2,101 mm year ${ }^{-1}$ at Gore, and $\leq 145 \mathrm{~mm}_{\text {year }}{ }^{-1}$ in the desert areas of Danakil Depression in Afar region.

Cognizant of this fact, one of the major objectives of the national malt barley improvement program has been to develop resilient malt barley varieties for production under such variable environmental conditions in the highlands of Ethiopia. Since its inception some 50 years ago, the Ethiopian national agricultural research system has released ten malt barley varieties with different yield potentials, malt qualities, adaptation areas and stability (Ministry of Agriculture [MoA], 2010). However, national malt barley productivity was not competitive enough for smallholder farmers to expand production due to weak technology transfer capacity (Rashid et al., 2015) and lack of well-structured land suitability information. In Ethiopia where smallholder farmers account $95 \%$ of agricultural production and $85 \%$ of all employment, $40 \%$ of the farming households operate on less than 0.5 ha, $64 \%$ on less than $1 \mathrm{ha}$, and $87 \%$ on less than 2 ha (FAO, 2011 citing Gebreselassie, 2007) although under rainfed agriculture an average family of 6 persons requires around 2.5 to 2.8 ha land to meet annual household requirements. This calls for agricultural intensification, where in our capacity, at least start with land suitability classification of malt barley varieties to improve productivity up to the potential of available natural resources and maintain the grain quality under the recommended management technologies.

The process of land suitability classification is the appraisal and grouping of specific areas of land in terms of their suitability for defined uses (FAO, 1976). Land suitability classification for agriculture is very important for future planning to help decision-makers and agricultural development planners determine how appropriate use of the land in a location is more suitable for certain agricultural use (Singha \& Swain, 2016). Geographic Information Systems (GIS) based land suitability analysis enables a large amount of different geospatial and associated information to be assembled, combined, overlaid, modeled and mapped. GIS has contributed to the speed and efficiency of the overall planning process in agricultural land use suitability since it enables quick and efficient access to large amounts of information, exhibiting relationships, patterns, and trends that are useful in monitoring land use potential and suitability evaluation. It is also useful tool for scaling proven technologies and packages of practices including the specific crops and crop varieties to address the yield and nutritional gaps (Singha \& Swain, 2016; Löw, Biradar, Dubovyk, Fliemann, Akramkhanov, Vallejo, \& Waldner, 2018).

Records show that GIS based land suitability evaluations for rainfed and irrigated agriculture in Ethiopia have been going on since 1989 (Radcliffe \& Bechtold, 1989; Rabia, 2012; Girma, Getahun, \& Babu, 2019). This process recently evolved to multi-criteria crop level land suitability analysis and mapping (Yitbarek, Kibret, Gebrekidan, \& Beyene, 2013; Selassie, Ayalew, Elias, \& Getahun, 2014; Yohannes \& Soromessa, 2018). The crop level suitability analysis results for malt barley indicated that there is $1,897,256$ ha of land which is highly suitable for malt barley production in Ethiopia (Nigussie, Tibebe, \& Demelash, 2018). However, crop level land suitability analysis does not consider variety by environment interactions and therefore does not indicate which variety fits best to which environmental conditions. It is, therefore, very important to map the agricultural land with its orographic and agroclimatic information to show the extent and distribution of land areas that are potentially suitable for contrasting malt barley varieties to enhance productivity and scaling in Ethiopia. Our integrated multi-criteria land suitability evaluation and mapping focused on physical environments such as soil type, soil depth, soil $\mathrm{pH}$, soil texture, soil drainage, land slope, altitude, length of growing period, rainfall, and temperature requirements of each test malt barley variety. 


\section{Materials and Methods}

\subsection{Study Area}

The study area, Ethiopia, is in geographic coordinates between $3^{\circ} 30^{\prime}$ and $14^{\circ} 50^{\prime} \mathrm{N}$ latitude, and $32^{\circ} 42^{\prime}$ and $48^{\circ} 12^{\prime} \mathrm{E}$ longitude with total surface area of $1,104,300 \mathrm{~km}^{2}$ of which about $1,000,000 \mathrm{~km}^{2}$ is land area (Kassie, 2014). It is a large and ecologically diverse country having nine regional states (Afar; Amhara; Benishangul-Gumuz [BSG]; Gambela; Harari; Oromia; Somali; Southern Nations, Nationalities and Peoples [SNNP]; Tigray) and two chartered cities (Addis Ababa and Dire Dawa). Each regional state is subdivided into administrative zones, districts and then to kebeles (the smallest administrative units). Our study excluded water bodies and land area of the two chartered cities and Harari Regional State.

Rainfall and temperature patterns vary widely because of Ethiopia's location in the tropics and its diverse topography. Moreover, the diversity of the country's terrain determines regional variations in climate, natural vegetation, and soil composition (Fazzini, Bisci, \& Billi, 2015; FAO, 2016; Jembere, Mamo, \& Kibret, 2017). Topographically, it consists of a central high plateau bisected by the Great Rift Valley into northern and southern highlands and surrounded by lowlands. The plateau varies from 1,500 to 3,000 meters above sea level and features mountainous uplands reaching the peak at Ras Dejen with the elevation of $4550 \mathrm{~m}$ above sea level (with the usual violent snow falls at night which melts when the temperature reaches $5-8{ }^{\circ} \mathrm{C}$ at midday), separated by deep gorges and river valleys. The lowlands lower than $1500 \mathrm{~m}$ above sea level ends with Danakil Depression in the east which is $115-125$ meters below sea level and is one of the hottest (as high as $50{ }^{\circ} \mathrm{C}$ ) places on earth.

\subsection{Crop Varieties}

Depending on data availability, varietal choices for malt barley were made based on the current production and altitude wise area coverage and recommendation in the technology transfer; productivity; earliness; plant height and straw yield to meet feed requirement for livestock; and grain protein content and seed boldness for malt quality. The malt barley varieties included in this analysis work are listed in Table 1.

Table 1. Selected characteristics of malt barley varieties used for land suitability mapping

\begin{tabular}{llllllll}
\hline Variety & $\begin{array}{l}\text { Year of } \\
\text { release }\end{array}$ & $\begin{array}{l}\text { Days to } \\
\text { flowering after } \\
\text { emergence* }\end{array}$ & $\begin{array}{l}\text { Grain yield with } \\
\text { recommended } \\
\text { management }\left(\mathbf{t ~ h a}^{-1}\right)\end{array}$ & $\begin{array}{l}\text { Grain protein } \\
\text { content } \mathbf{( \% )}\end{array}$ & $\begin{array}{l}\text { Thousand grain } \\
\text { weight (g) }\end{array}$ & $\begin{array}{l}\text { Plant height } \\
\text { at heading* (cm) }\end{array}$ & $\begin{array}{l}\text { Recommended } \\
\text { altitude (masl) }\end{array}$ \\
\hline Bekoji-1 & 2010 & 77 & $3.5-5.0$ & 11.7 & 46.6 & 108.8 & $2,300-2,800$ \\
EH1847 & 2011 & 80 & $3.5-4.4$ & 11.2 & 46.0 & 101.2 & $2,200-2,800$ \\
Grace & 2013 & $\mathrm{Na}$ & $2.0-4.0$ & 10.5 & 42.0 & na & $2,000-2,400$ \\
Holker & 1979 & 80 & $2.4-3.1$ & 10.4 & 41.1 & 104.0 & $2,500-3,000$ \\
IBON174/03 & 2012 & 67 & $3.0-5.7$ & 10.0 & 46.5 & 88.2 & $2,000-2,800$ \\
Sabini & 2011 & 72 & $2.5-4.9$ & 8.5 & 45.0 & 87.6 & $2,300-2,500$ \\
\hline
\end{tabular}

Note. na $=$ no data available for it was not tested at DBARC.

Source: National Seed Industry Agency (NSIA), 1998; Ministry of Agriculture (MoA), 2010-212; Ministry of Agriculture and Rural Development (MoARD), 2013; and unpublished Regional Variety Trial data submitted to MoA; *unpublished data of Debre Birhan Agricultural Research Center (DBARC) at 2,810 masl.

\subsection{Geospatial Data}

To carry out a land suitability evaluation, spatial data layers were prepared. The main factors affecting plant growth parameters were included in the analysis: climate layers, topography (digital elevation models, i.e., altitude and slope data), soil types and soil properties [chemical $(\mathrm{pH})$ and physical (depth, texture, and drainage)]. Administrative boundaries and infrastructure (roads, towns, and other facilities) were also used to prepare the final map and generate the tabular data.

Greater emphasis was given to altitude as it largely influences climate which plays a major role in crop production (Hurni, 1998). The climate data used were rainfall and temperature surface maps (during the growing period) interpolated at a resolution of about $300 \mathrm{~m}$ which again resampled to $200 \mathrm{~m}$ to match the $200 \mathrm{~m}$ analysis resolution; and length of growing period with a slight modification (i.e., joining the values of dependable length of period and converting to raster (pixel based)). Source of these data was Woody Biomass Inventory and Strategic Planning Project (WBISPP, 2004) of the Ethiopian Ministry of Agriculture. Climatic conditions can vary widely from year to year, and this was addressed by using long-term average of rainfall and temperature; 
this approach is valid if the aim is to assess overall suitability or potential and not to model crop growth in any one year (Pettapiece, 1995).

The soil properties were extracted from the Soil and Terrain Database of East Africa and gridded soil database of $250 \mathrm{~mm}$ (International Soil Reference Information Center [ISRIC], 2015), while the soil type used was from WBISPP (2004). For the altitude information, the Shuttle Radar Topography Mission (SRTM) $90 \mathrm{~m}$ digital elevation model (DEM) database (Jarvis, Reuter, Nelson and Guevara, 2008) was used and the same DEM used for topographic analysis such as generating slope maps. These data were resampled to a common spatial resolution of $200 \mathrm{~m}$ for the spatial analysis in the GIS domain.

\subsection{Defining the Limits of Environmental Requirements for Malt Barley Varieties}

To define the suitability classes according to the land use types, several literatures (e.g., NSIA, 1998; MoA, 2010-2012; MoARD, 2013; unpublished research reports in the national agricultural research system) and qualified researchers were consulted. The land evaluations study conducted by FAO (1984), and by Sys, Ranst, Debaveye, and Beernaert (1993) were used as a general guide to derive thresholds for defining the suitability categories.

For classification of the data layers according to the degree of suitability for each variety specific to environmental conditions, the existing digital and analogue maps, reports, and other relevant information were reviewed and used in defining the limits of the suitability ranges of each malt barley variety. The environmental requirements of the target varieties were defined by means of a set of critical values, which determine the limits between the land suitability classes. The suitability classes, reflecting the degree of suitability, were set as $\mathrm{S}_{1}$ (highly suitable), $\mathrm{S}_{2}$ (moderately suitable), and $\mathrm{S}_{3}$ (marginally suitable) and $\mathrm{N}$ (not suitable) based on the assumptions indicated in the FAO land suitability classification structure presented in Table 2. According to FAO classification, $\mathrm{S}_{1}$ corresponds to $85-100 \%, \mathrm{~S}_{2}$ to $60-85 \%, \mathrm{~S}_{3}$ to $40-60 \%, \mathrm{~N}_{1}$ to $25-40 \%$ and $\mathrm{N}_{2}$ to $25-0 \%$ (Elsheikh $\&$ Abdalla, 2016) of optimum yield under the recommended management practices.

Table 2. Structure of the FAO land suitability classification

\begin{tabular}{lll}
\hline Code & Class name & Description \\
\hline $\mathrm{S}_{1}$ & Highly suitable & $\begin{array}{l}\text { Land having no significant limitations to sustained application of a given use, or only } \\
\text { minor limitations that will not significantly reduce productivity and will not raise inputs } \\
\text { above an acceptable level. } \\
\text { Land having limitations which, in aggregate, are moderately severe for sustained } \\
\text { application of a given use; the limitations will reduce productivity and increase required } \\
\text { inputs to the extent that the overall advantage to be gained from the use, although still } \\
\text { attractive, will be appreciably low to that expected on } \mathrm{S}_{1} \text { land. }\end{array}$ \\
$\mathrm{S}_{2}$ & Moderately suitable & $\begin{array}{l}\text { Land having limitations which, in aggregate, are severe for sustained application of a } \\
\text { given use and will so reduce productivity or benefits, or increase required inputs, that this } \\
\text { expenditure will be only marginally justified. } \\
\text { Land that cannot support the land use on a sustained basis, or land on which benefits do not } \\
\mathrm{S}_{3}\end{array} \quad$ Marginally suitable \\
$\mathrm{N}$ & Not suitable &
\end{tabular}

Source. FAO, 1976, 1993.

Since the analysis is raster (pixel) based, some of the data, which were in vector format (object based), were converted to uniform raster datasets. The important GIS layers of environmental factors affecting the growth of malt barley varieties were identified and each layer's pixel values were classified and assigned weight. Following this, the environmental factor layers were compared among themselves and ranked. Based on the rate and rank assigned to each pixel, the land suitability map for each variety was computed. The classification of each layer into suitability categories was done using Reclass by Table function in ArcGIS spatial analyst (ESRI GIS package) tool. The reclassification is implemented in the model by preparing separate tables for each factor/criteria layer and malt barley variety. The environmental requirements of the target varieties were defined by means of a set of critical values, which determine the limits between the land suitability classes. Because of space limitations, it is difficult to show all details of defined critical values of each variety's environmental requirements, thus, some selected examples by grouping the varieties into late versus early are presented in Table 3. Early malt barley varieties are Grace, IBON 174/03 and Sabini while late maturing ones are Bekoji-1, EH1847 and Holker. 
Table 3. Environmental information used in land suitability mapping of early versus late maturing malt barley varieties

\begin{tabular}{|c|c|c|c|c|c|}
\hline \multirow{2}{*}{$\begin{array}{l}\text { Maturity group } \\
\text { of varieties }\end{array}$} & \multirow{2}{*}{$\begin{array}{l}\text { Environmental } \\
\text { parameters }\end{array}$} & \multicolumn{4}{|c|}{ Critical values/ratings in each suitability class } \\
\hline & & $\mathrm{S}_{1}$ & $\mathbf{S}_{2}$ & $\mathrm{~S}_{3}$ & $\mathbf{N}$ \\
\hline Early & \multirow{2}{*}{ Altitude (masl) } & $2000-3000$ & $1800-2000 ; 3000-3200$ & $1500-1800 ; 3200-3500$ & $<1500 ;>3500$ \\
\hline Late & & $2600-3000$ & $2400-2600 ; 3000-3100$ & $2000-2400 ; 3100-3200$ & $<2000 ;>3200$ \\
\hline Early & \multirow{2}{*}{ Rainfall (mm) } & $900-1400$ & $700-900 ; 1400-1600$ & $500-700 ; 1600-1800$ & $<500 ;>1800$ \\
\hline Late & & $900-1400$ & $800-900 ; 1400-1500$ & $600-800 ; 1500-1600$ & $<600 ;>1600$ \\
\hline Early & \multirow{2}{*}{ Temperature $\left({ }^{0} \mathrm{C}\right)$} & $12-17$ & $10-12 ; 17-19$ & $8-10 ; 19-21$ & $<8 ;>21$ \\
\hline Late & & $11-13$ & $10-11 ; 13-15$ & $9-10 ; 15-17$ & $<9 ;>17$ \\
\hline Early & \multirow{2}{*}{ LGP (days) } & $110-180$ & $100-110 ; 180-190$ & $90-100 ; 190-200$ & $<90 ;>200$ \\
\hline Late & & $150-180$ & $140-150 ; 180-190$ & $120-140 ; 190-200$ & $<120 ;>200$ \\
\hline Early & Soil type & $\begin{array}{l}\text { Nitosols, Cambisols, } \\
\text { Luvisols, Phaeozems }\end{array}$ & $\begin{array}{l}\text { Fluvisols, Andosols, } \\
\text { Gleysols, Histosols, } \\
\text { Chernozems }\end{array}$ & $\begin{array}{l}\text { Vertisols, Acrisols, } \\
\text { Rendzinas }\end{array}$ & $\begin{array}{l}\text { Lithosols, Regosols, } \\
\text { Xarosols, Solonchaks, } \\
\text { Yermosols }\end{array}$ \\
\hline Early & Texture class & $\begin{array}{l}\text { Loam, Silt-loam, Sandy } \\
\text { clay-loam }\end{array}$ & $\begin{array}{l}\text { Clay-loam, Silty } \\
\text { clay-loam }\end{array}$ & $\begin{array}{l}\text { Sandy-loam, } \\
\text { Sandy-clay, Silt, } \\
\text { Silty-clay, Clay }\end{array}$ & Sand, Loamy sand \\
\hline Early & Drainage class & Well drained & $\begin{array}{l}\text { Somewhat excessively } \\
\text { drained, Moderately } \\
\text { well drained }\end{array}$ & $\begin{array}{l}\text { Excessively drained, } \\
\text { Imperfectly drained }\end{array}$ & Poor \\
\hline $\begin{array}{l}\text { Early } \\
\text { Late }\end{array}$ & Soil pH & $6.0-7.5$ & $5.0-6.0 ; 7.5-8.0$ & $4.5-5.0 ; 8.0-8.5$ & $<4.5 ;>8.5$ \\
\hline $\begin{array}{l}\text { Early } \\
\text { Late }\end{array}$ & Soil depth (cm) & $>80$ & $60-80$ & $40-60$ & $<40$ \\
\hline $\begin{array}{l}\text { Early } \\
\text { Late }\end{array}$ & Slope (\%) & $2-15$ & $15-25$ & $1-2 ; 25-30$ & $<1 ;>30$ \\
\hline
\end{tabular}

Note. masl $=$ metere above sea level; LGP $=$ length of growing period mainly affected by altitude (through influencing climatic variables) and water holding capacity of soil.

\subsection{Calculation of Weight for Criteria Layers and Overall Suitability Analysis}

The overall suitability map is the combined result of the altitude, slope, soil types and soil properties, and the climate layers. The weighted overlay approach built on ArcGIS ModelBuilder was used for the overlay analysis to solve such multi-criteria problems of suitability. The suitability criteria layers were assigned weights to account for their relative importance and overlaid using the weighted overlay tool to produce the overall land suitability map. The purpose of weighting is to express the relative importance of each factor regarding the effects on crop yield and growth rate (Perveen, Nagasawa, Uddin, \& Delowar, 2007).

The analytic hierarchy process (AHP) developed by Saaty (1987) was used to calculate the weights for the different criteria. AHP relies on pairwise comparisons that assign values based on relative importance of criteria layers. The criteria were evaluated, and numerical scales of measurement were derived through comparing against the goal for importance. The pairwise comparison scales were assigned through discussion among experts. The overall suitability is computed by multiplying the selected criteria weight (Wi) by the assigned sub-criteria score (Xi) and summing these values in the ArcGIS Model Builder (see Equation 1):

$$
\mathrm{S}=\sum_{i=1}^{n} \mathrm{Wi} \cdot \mathrm{Xi}
$$

where, $\mathrm{S}$ denotes the final land suitability score, Wi denotes the weight of the corresponding suitability criteria, $\mathrm{Xi}$ denotes the assigned sub-criteria score of $\mathrm{i}$ suitability criteria and $n$ is the total number of criteria maps.

The final suitability result (maps and tabular data) including the explanatory document are prepared both in softcopy and hardcopy. The eventual relative weight values of these multi-criteria are 16.90, 14.40, 12.54, 9.75, $9.75,9.44,8.70,7.71,5.65$ and $5.16 \%$ for altitude, rainfall, temperature, soil type, texture, length of growing period, drainage, soil $\mathrm{pH}$, soil depth and slope, respectively. The flow diagram shows the steps followed for suitability analysis (Figure 1): 


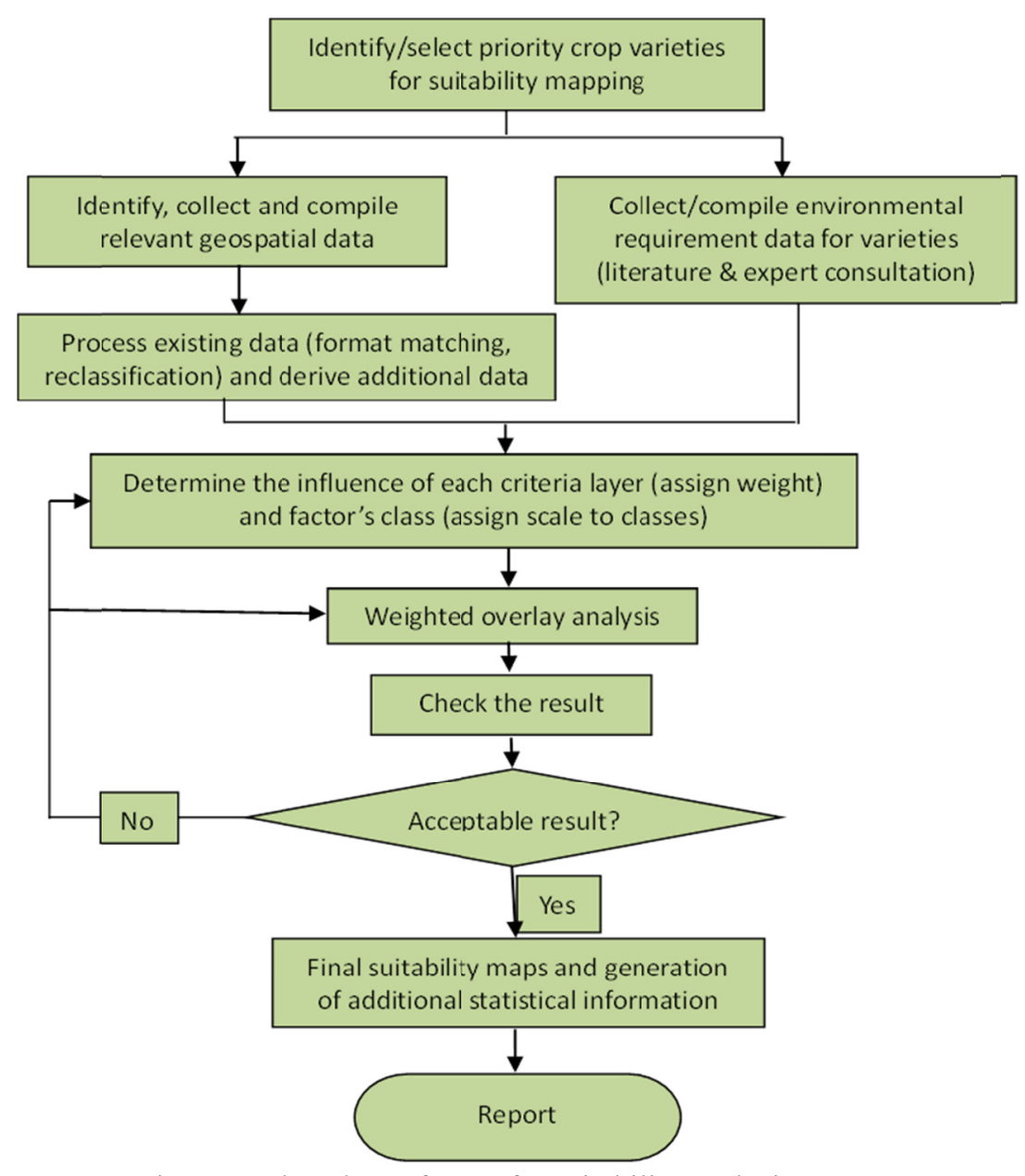

Figure 1. Flowchart of steps for suitability analysis

\section{Results}

In addition to the presentation of the result for each variety in the subsequent sub-sections, major administrative zones with relatively larger proportion of highly suitable $\left(\mathrm{S}_{1}\right)$ and moderately suitable $\left(\mathrm{S}_{2}\right)$ land areas among target administrative zones in regional states of Ethiopia are presented in Table 4 for better understanding and comparison of differences among malt barley varieties. For each variety, 15 administrative zones are listed in decreasing order of land area for $S_{1}$ and $S_{2}$ across the regional states. 
Table 4. Malt barley varieties and administrative zones with relatively larger land area for $\mathrm{S}_{1}$ and $\mathrm{S}_{2}$ in Ethiopia

\begin{tabular}{|c|c|c|c|}
\hline Variety & Suitability classes & Land area (ha) & Major administrative zones \\
\hline \multirow{2}{*}{ Bekoji-1 } & $\mathrm{S}_{1}$ & 125,332 & $\begin{array}{l}\text { West Shewa, South Wollo, North Shewa of Amhara Region, North Gonder, South } \\
\text { Gonder, Guji, South West Shewa, Horo Guduru, East Shewa, Arsi, West Gojam, } \\
\text { East Gojam, North Shewa of Oromia Region, West Arsi, Borena }\end{array}$ \\
\hline & $\mathrm{S}_{2}$ & $4,342,044$ & $\begin{array}{l}\text { Jimma, Arsi, Ilubabor, West Shewa, Bale, West Arsi, East Gojam, North Shewa of } \\
\text { Oromia Region, West Gojam, South Wollo, Keffa, South Gonder, Guji, East Wellega, } \\
\text { North Shewa of Amhara Region }\end{array}$ \\
\hline \multirow{2}{*}{ EH 1847} & $\mathrm{~S}_{1}$ & 124,004 & $\begin{array}{l}\text { West Shewa, North Shewa of Amhara Region, South West Shewa, South Gonder, } \\
\text { Gamo Gofa, Gurage, East Gojam, North Shewa of Oromia Region, Selti, Jimma, } \\
\text { North Gonder, South Wollo, Hadiya, South Omo, Dawro }\end{array}$ \\
\hline & $\mathrm{S}_{2}$ & $4,330,932$ & $\begin{array}{l}\text { Arsi, West Arsi, West Shewa, North Shewa of Oromia Region, North Shewa of } \\
\text { Amhara Region, South Wollo, Jimma, Bale, Gurage, Gamo Gofa, East Gojam, } \\
\text { Keffa, Sidama, South West Shewa, Guji }\end{array}$ \\
\hline \multirow{2}{*}{ Grace } & $\mathrm{S}_{1}$ & 775,312 & $\begin{array}{l}\text { West Shewa, South Wollo, North Shewa of Amhara Region, North Gonder, South } \\
\text { Gonder, Guji, South West Shewa, Horo Guduru, East Shewa, Arsi, West Gojam, } \\
\text { East Gojam, North Shewa of Oromia Region, West Arsi, Borena }\end{array}$ \\
\hline & $\mathrm{S}_{2}$ & $20,648,764$ & $\begin{array}{l}\text { Jimma, Arsi, llubabor, West Shewa, Bale, West Arsi, East Gojam, North Shewa of } \\
\text { Oromia Region, West Gojam, South Wollo, Keffa, South Gonder, Guji, East } \\
\text { Wellega, North Shewa of Amhara Region }\end{array}$ \\
\hline \multirow{2}{*}{ Holker } & $\mathrm{S}_{1}$ & 125,356 & $\begin{array}{l}\text { West Shewa, South West Shewa, North Shewa of Amhara Region, South Gonder, } \\
\text { Gamo Gofa, Gurage, Jimma, East Gojam, Selti, North Shewa of Oromia Region, } \\
\text { North Gonder, South Wollo, Hadiya, South Omo, Dawro }\end{array}$ \\
\hline & $\mathrm{S}_{2}$ & $4,342,756$ & $\begin{array}{l}\text { Arsi, West Arsi, West Shewa, North Shewa of Oromia Region, North Shewa of } \\
\text { Amhara Region, South Wollo, Jimma, Bale, Gurage, Gamo Gofa, East Gojam, } \\
\text { Keffa, Sidama, South West Shewa, Guji }\end{array}$ \\
\hline \multirow{2}{*}{ IBON 174/03 } & $\mathrm{S}_{1}$ & $1,677,388$ & $\begin{array}{l}\text { West Shewa, North Shewa of Amhara Region, South Gonder, South Wollo, East } \\
\text { Gojam, North Shewa of Oromia Region, West Gojam, North Gonder, South West } \\
\text { Shewa, East Harerge, Jimma, Horo Guduru, Arsi, Guji, Gurage }\end{array}$ \\
\hline & $\mathrm{S}_{2}$ & $11,588,156$ & $\begin{array}{l}\text { Arsi, Jimma, West Arsi, North Shewa of Oromia Region, South Wollo, East Gojam, } \\
\text { North Shewa of Amhara Region, West Shewa, Keffa, Bale, Guji, Sidama, South } \\
\text { West Shewa, Ilubabor, North Wollo }\end{array}$ \\
\hline \multirow{2}{*}{ Sabini } & $\mathrm{S}_{1}$ & 307,952 & $\begin{array}{l}\text { West Shewa, South West Shewa, South Gonder, North Gonder, South Wollo, East } \\
\text { Harerge, Arsi, North Shewa of Amhara Region, West Gojam, Guji, East Gojam, } \\
\text { North Shewa of Oromia Region, Gedio, Bale, West Harerge }\end{array}$ \\
\hline & $\mathrm{S}_{2}$ & $16,358,348$ & $\begin{array}{l}\text { Jimma, Arsi, West Shewa, West Arsi, East Gojam, North Shewa of Oromia Region, } \\
\text { South Wollo, North Shewa of Amhara Region, Ilubabor, Keffa, South Gonder, Guji, } \\
\text { South West Shewa, Bale, Sidama }\end{array}$ \\
\hline
\end{tabular}

Note. An administrative zone may have highly suitable and/or moderately suitable areas as it covers large and diverse geographic area.

The results of the land suitability analysis for each variety are presented in the subsequent sub-sections to show the extent and patterns of land area available for production and scaling up of target malt barley varieties in Ethiopia.

\subsection{Variety Bekoji-1 (EH1293/F2-18B-11-1-14-18)}

Land suitability analysis and mapping results for variety Bekoji-1 are shown in Table 5 and Figure 2. As indicated in Table 1, variety Bekoji-1 is a relatively high yielding and late-maturing variety which performs best in frost free long growing period in high altitude highlands. Highly suitable areas where it is expected to express its higher potential is very limited, 125,332 ha, as compared to other relatively early maturing varieties like IBON 174/03 (Table 4). 
Table 5. Land area and suitability classes for malt barley variety Bekoji-1 production in Ethiopia

\begin{tabular}{|c|c|c|c|c|c|c|c|c|}
\hline \multirow{2}{*}{ Regional states } & \multicolumn{2}{|c|}{ Highly Suitable } & \multicolumn{2}{|c|}{ Moderately Suitable } & \multicolumn{2}{|c|}{ Marginally Suitable } & \multicolumn{2}{|c|}{ Not Suitable } \\
\hline & Area (ha) & $\% *$ & Area (ha) & $\% *$ & Area (ha) & $\% *$ & Area (ha) & $\% *$ \\
\hline Amhara & 35,240 & 0.23 & 860,992 & 5.53 & 3,892 & 0.03 & $14,663,245$ & 94.22 \\
\hline Oromia & 75,392 & 0.23 & $2,513,736$ & 7.75 & 128,084 & 0.39 & $29,732,201$ & 91.63 \\
\hline SNNP & 14,700 & 0.13 & 961,160 & 8.51 & 31,268 & 0.28 & $10,282,858$ & 91.08 \\
\hline Tigray & 0 & 0 & 3,400 & 0.07 & 0 & 0 & $5,017,258$ & 99.93 \\
\hline Afar & 0 & 0 & 0 & 0 & 0 & 0 & $9,562,336$ & 100 \\
\hline BSG & 0 & 0 & 2,668 & 0.05 & 0 & 0 & $4,997,689$ & 99.95 \\
\hline Gambella & 0 & 0 & 88 & 0 & 0 & 0 & $2,570,048$ & 100 \\
\hline Somali & 0 & 0 & 0 & 0 & 0 & 0 & $31,561,965$ & 100 \\
\hline Total & 125,332 & 0.11 & $4,342,044$ & 3.84 & 163,244 & 0.14 & $108,387,600$ & 95.90 \\
\hline
\end{tabular}

Note. $\mathrm{SNNP}=$ Southern Nations, Nationalities and Peoples; BSG $=$ Benishangul-Gumuz; $* \%$ refers to percent area for each suitability class calculated against the total area for each Regional State.

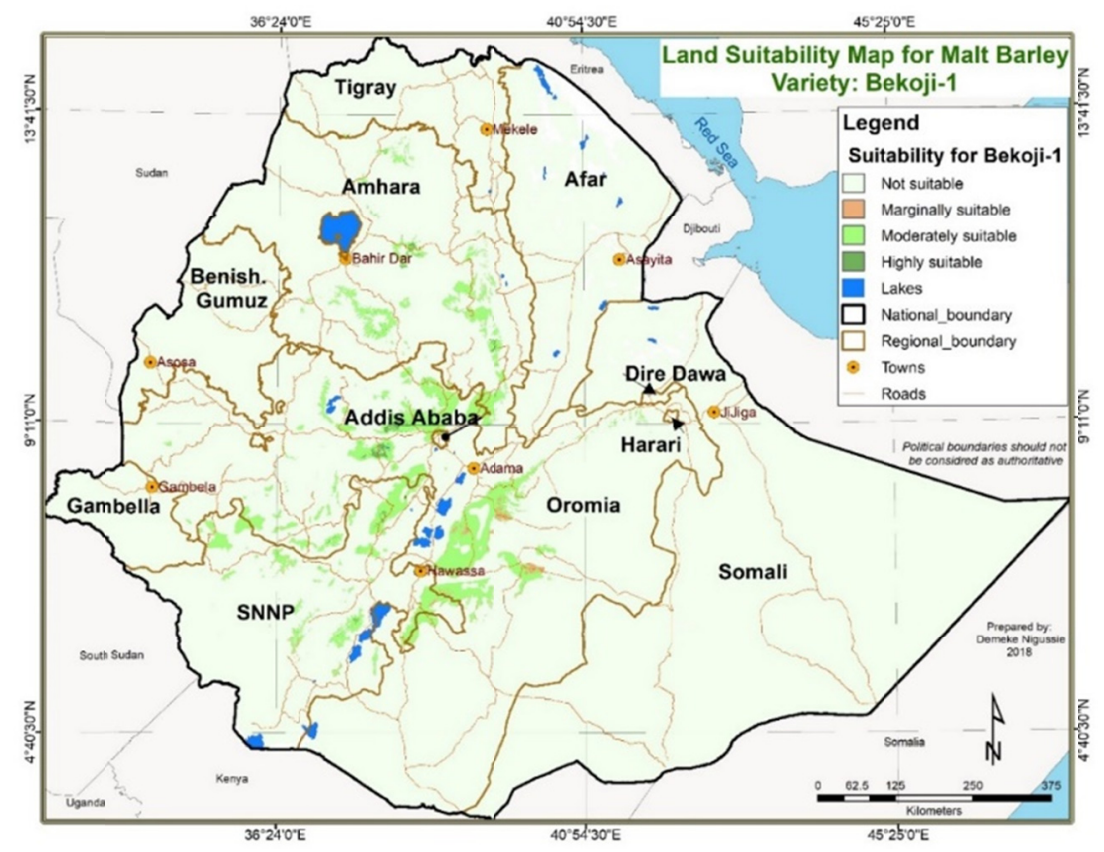

Figure 2. Land suitability map for malt barley variety Bekoji-1

\subsection{Variety EH1847 [F4.2P.5.2 (Bea/IBON 64/91)]}

EH1 847 variety, like Bekoji-1 and Holker, is also a late-maturing and tall variety with the average yield potential of 3.5-4.4 t ha $\mathrm{h}^{-1}$ in research fields under recommended management (Table 1). The variety level suitability analysis and mapping results for this variety are presented in Table 6 and Figure 3. The analysis results showed that highly suitable land areas for variety EH1847 are the lowest (124,004 ha) as compared to that of other varieties analyzed in this work (Table 4). Late maturing varieties like EH1847 perform best in frost free long growing periods in the high altitude highlands of Ethiopia. 
Table 6. Land area and suitability classes for malt barley variety EH1847 production in Ethiopia

\begin{tabular}{|c|c|c|c|c|c|c|c|c|}
\hline \multirow{2}{*}{ Regional states } & \multicolumn{2}{|c|}{ Highly Suitable } & \multicolumn{2}{|c|}{ Moderately Suitable } & \multicolumn{2}{|c|}{ Marginally Suitable } & \multicolumn{2}{|c|}{ Not Suitable } \\
\hline & Area (ha) & $\% *$ & Area (ha) & $\% *$ & Area (ha) & $\% *$ & Area (ha) & $\% *$ \\
\hline Amhara & 35,280 & 0.23 & 860,068 & 5.53 & 4,776 & 0.03 & $14,663,245$ & 94.22 \\
\hline Oromia & 74,780 & 0.23 & $2,510,864$ & 7.74 & 131,136 & 0.4 & $29,732,633$ & 91.63 \\
\hline SNNP & 13,944 & 0.12 & 953,844 & 8.45 & 38,348 & 0.34 & $10,283,850$ & 91.09 \\
\hline Tigray & 0 & 0 & 3,400 & 0.07 & 0 & 0 & $5,017,258$ & 99.93 \\
\hline Afar & 0 & 0 & 0 & 0 & 0 & 0 & $9,562,336$ & 100 \\
\hline BSG & 0 & 0 & 2,668 & 0.05 & 0 & 0 & $4,997,689$ & 99.95 \\
\hline Gambella & 0 & 0 & 88 & 0 & 0 & 0 & $2,570,048$ & 100 \\
\hline Somali & 0 & 0 & 0 & 0 & 0 & 0 & $31,561,965$ & 100 \\
\hline Total & 124,004 & 0.11 & $4,330,932$ & 3.83 & 174,260 & 0.15 & $108,389,024$ & 95.90 \\
\hline
\end{tabular}

Note. SNNP = Southern Nations, Nationalities and Peoples; BSG = Benishangul-Gumuz; * \% refers to percent area for each suitability class calculated against the total area for each Regional State.

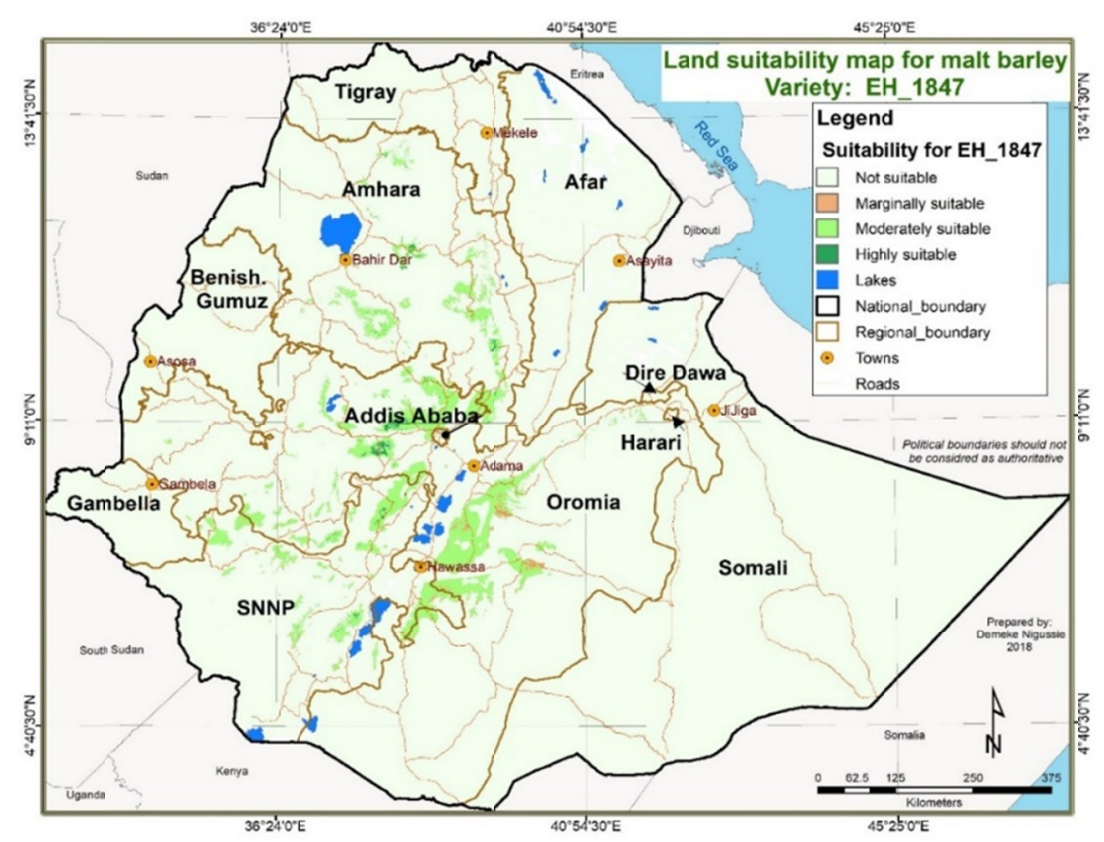

Figure 3. Land suitability map for malt barley variety EH1847

\subsection{Variety Grace}

Grace is an early maturing malt barley variety with the average yield potential of 2.0-4.0 $\mathrm{tha}^{-1}$ in research fields under recommended management (Table 1). The variety level suitability analysis and mapping results for this variety are presented in Table 7 and Figure 4. Being relatively early maturing and resistant to net blotch, the suitability analysis results for variety Grace show that it fits to the second largest highly suitable land areas of 775,312 ha when compared with other target varieties in Table 4. 
Table 7. Land area and suitability classes for malt barley variety Grace production in Ethiopia

\begin{tabular}{|c|c|c|c|c|c|c|c|c|}
\hline \multirow{2}{*}{ Regional states } & \multicolumn{2}{|c|}{ Highly Suitable } & \multicolumn{2}{|c|}{ Moderately Suitable } & \multicolumn{2}{|c|}{ Marginally Suitable } & \multicolumn{2}{|c|}{ Not Suitable } \\
\hline & Area (ha) & $\% *$ & Area (ha) & \%* & Area (ha) & $\% *$ & Area (ha) & $\% *$ \\
\hline Amhara & 360,748 & 2.32 & $4,943,524$ & 31.76 & 17,128 & 0.11 & $10,241,969$ & 65.81 \\
\hline Oromia & 359,520 & 1.11 & $11,363,196$ & 35.02 & 163,200 & 0.5 & $20,563,497$ & 63.37 \\
\hline SNNP & 48,388 & 0.43 & $4,155,640$ & 36.81 & 121,596 & 1.08 & $6,964,362$ & 61.69 \\
\hline Tigray & 6,640 & 0.13 & 45,428 & 0.9 & 0 & 0 & $4,968,590$ & 98.96 \\
\hline Afar & 0 & 0 & 108 & 0 & 0 & 0 & $9,562,228$ & 100 \\
\hline BSG & 16 & 0 & 108,048 & 2.16 & 1,072 & 0.02 & $4,891,221$ & 97.82 \\
\hline Gambella & 0 & 0 & 13,364 & 0.52 & 0 & 0 & $2,556,772$ & 99.48 \\
\hline Somali & 0 & 0 & 19,456 & 0.06 & 276 & 0 & $31,542,233$ & 99.94 \\
\hline Total & 775,312 & 0.69 & $20,648,764$ & 18.27 & 303,272 & 0.27 & $91,290,872$ & 80.78 \\
\hline
\end{tabular}

Note. SNNP = Southern Nations, Nationalities and Peoples; BSG = Benishangul-Gumuz; * \% refers to percent area for each suitability class calculated against the total area for each Regional State.

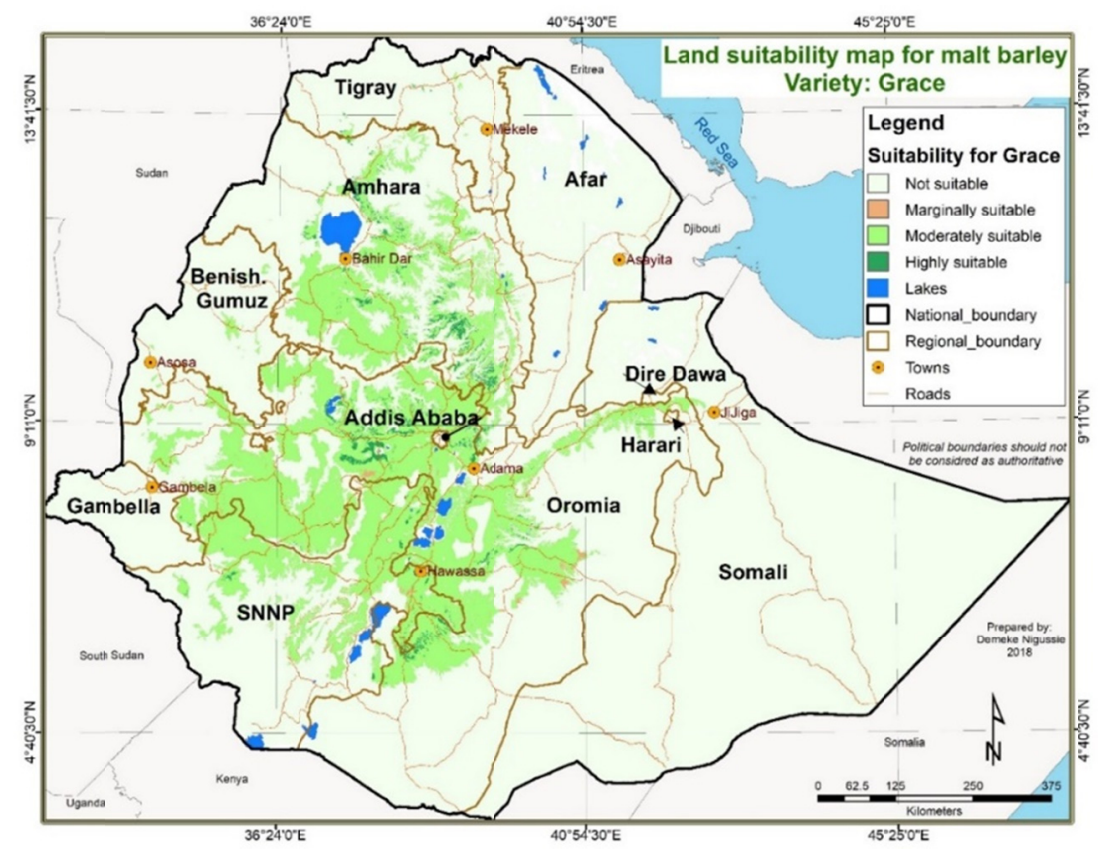

Figure 4. Land suitability map for malt barley variety Grace

\subsection{Variety Holker}

The variety level suitability analysis and mapping results for this variety are presented in Table 8 and Figure 5 . Holker is like Bekoji-1 and EH1847 varieties is late maturing, its niche for expressing its potential is a frost free 125,356 ha of land with long growing period in high altitude highlands of Ethiopia. 
Table 8. Land area and suitability classes for malt barley variety Holker production in Ethiopia

\begin{tabular}{|c|c|c|c|c|c|c|c|c|}
\hline \multirow{2}{*}{ Regional states } & \multicolumn{2}{|c|}{ Highly Suitable } & \multicolumn{2}{|c|}{ Moderately Suitable } & \multicolumn{2}{|c|}{ Marginally Suitable } & \multicolumn{2}{|c|}{ Not Suitable } \\
\hline & Area (ha) & $\% *$ & Area (ha) & $\% *$ & Area (ha) & $\% *$ & Area (ha) & $\% *$ \\
\hline Amhara & 35,172 & 0.23 & 861,060 & 5.53 & 3,892 & 0.03 & $14,663,245$ & 94.22 \\
\hline Oromia & 75,484 & 0.23 & $2,514,372$ & 7.75 & 127,356 & 0.39 & $29,732,201$ & 91.63 \\
\hline SNNP & 14,700 & 0.13 & 961,168 & 8.51 & 31,260 & 0.28 & $10,282,858$ & 91.08 \\
\hline Tigray & 0 & 0 & 3,400 & 0.07 & 0 & 0 & $5,017,258$ & 99.93 \\
\hline Afar & 0 & 0 & 0 & 0 & 0 & 0 & $9,562,336$ & 100 \\
\hline BSG & 0 & 0 & 2,668 & 0.05 & 0 & 0 & $4,997,689$ & 99.95 \\
\hline Gambella & 0 & 0 & 88 & 0 & 0 & 0 & $2,570,048$ & 100 \\
\hline Somali & 0 & 0 & 0 & 0 & 0 & 0 & $31,561,965$ & 100 \\
\hline Total & 125,356 & 0.11 & $4,342,756$ & 3.84 & 162,508 & 0.14 & $108,387,600$ & 95.90 \\
\hline
\end{tabular}

Note. $\mathrm{SNNP}=$ Southern Nations, Nationalities and Peoples; BSG $=$ Benishangul-Gumuz; $* \%$ refers to percent area for each suitability class calculated against the total area for each Regional State.

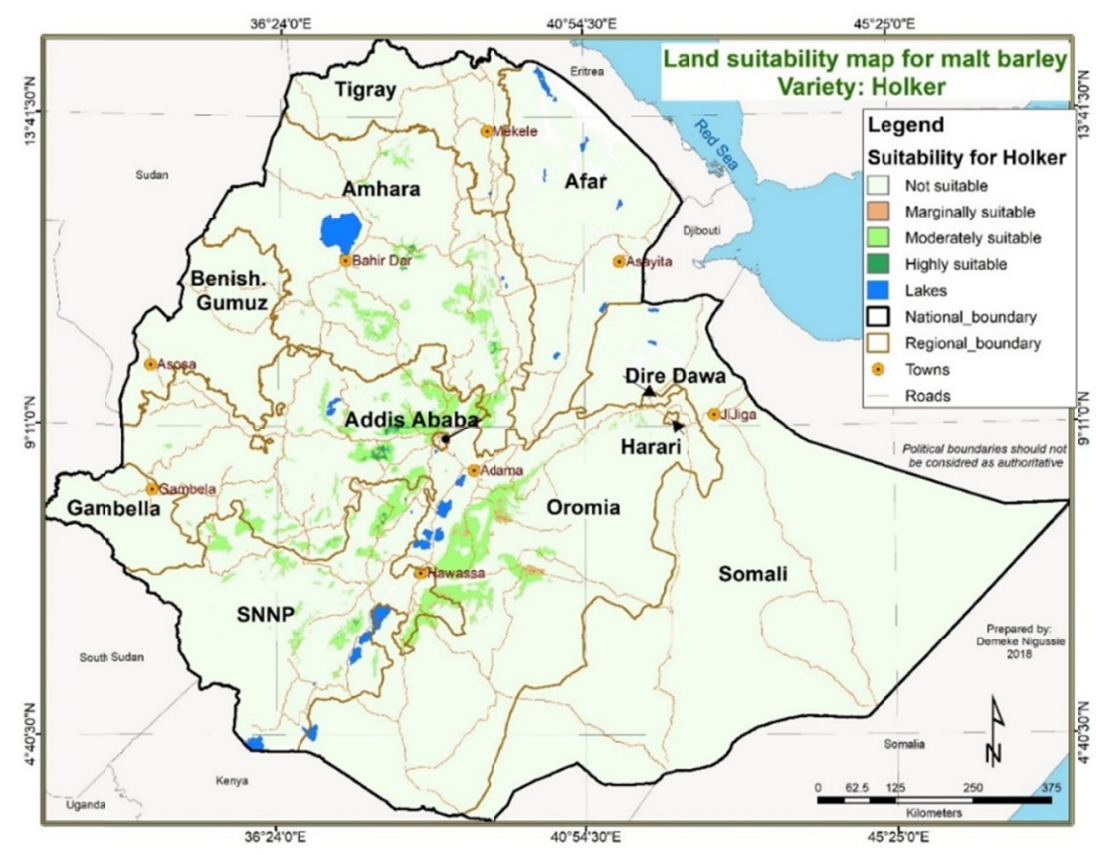

Figure 5. Land suitability map for malt barley variety Holker

\subsection{Variety IBON 174/03}

Average yield potential of variety IBON 174/03 was reported to be $3.0-5.7 \mathrm{t} \mathrm{ha}^{-1}$ in research fields under recommended management (Table 1). It is tolerant to scald and resistant to leaf blotch. IBON 174/03 is also an early maturing variety escaping terminal stresses such as moisture deficit and relatively higher temperature in mid altitude areas, and frost damage in high altitude highlands of Ethiopia. Land suitability analysis and mapping results for this variety are shown in Table 9 and Figure 6. Its earliness and disease resistance helped it fit to the largest land area $(1,677,388 \mathrm{ha})$ of highly suitable class as compared to other early and late maturing varieties (Table 4). 
Table 9. Land area and suitability classes for malt barley variety IBON 174/03 production in Ethiopia

\begin{tabular}{|c|c|c|c|c|c|c|c|c|}
\hline \multirow{2}{*}{ Regional states } & \multicolumn{2}{|c|}{ Highly Suitable } & \multicolumn{2}{|c|}{ Moderately Suitable } & \multicolumn{2}{|c|}{ Marginally Suitable } & \multicolumn{2}{|c|}{ Not Suitable } \\
\hline & Area (ha) & $\% *$ & Area (ha) & $\% *$ & Area (ha) & $\% *$ & Area (ha) & $\% *$ \\
\hline Amhara & 845,712 & 5.43 & $2,888,004$ & 18.56 & 4,120 & 0.03 & $11,825,533$ & 75.98 \\
\hline Oromia & 738,680 & 2.28 & $6,108,104$ & 18.82 & 17,440 & 0.05 & $25,585,189$ & 78.85 \\
\hline SNNP & 78,508 & 0.7 & $2,551,312$ & 22.6 & 11,232 & 0.1 & $8,648,934$ & 76.61 \\
\hline Tigray & 8,044 & 0.16 & 3,608 & 0.07 & 0 & 0 & $5,009,006$ & 99.77 \\
\hline Afar & 0 & 0 & 0 & 0 & 0 & 0 & $9,562,336$ & 100 \\
\hline BSG & 6,444 & 0.13 & 33,160 & 0.66 & 0 & 0 & $4,960,753$ & 99.21 \\
\hline Gambella & 0 & 0 & 3,968 & 0.15 & 0 & 0 & $2,566,168$ & 99.85 \\
\hline Somali & 0 & 0 & 0 & 0 & 0 & 0 & $31,561,965$ & 100 \\
\hline Total & $1,677,388$ & 1.48 & $11,588,156$ & 10.25 & 32,792 & 0.03 & $99,719,884$ & 88.23 \\
\hline
\end{tabular}

Note. $\mathrm{SNNP}=$ Southern Nations, Nationalities and Peoples; $\mathrm{BSG}=$ Benishangul-Gumuz; $* \%$ refers to percent area for each suitability class calculated against the total area for each Regional State.

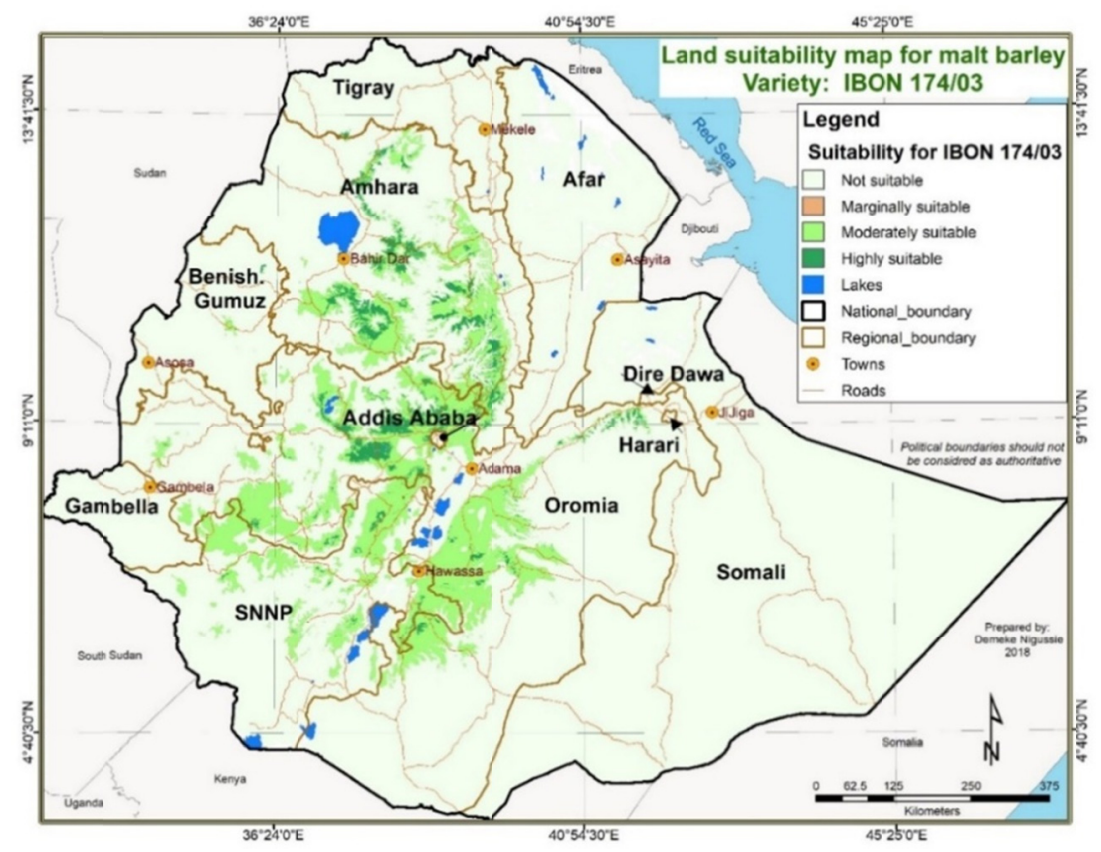

Figure 6. Land suitability map for malt barley variety IBON 174/03

\subsection{Variety Sabini}

Sabini is an early maturing variety with the average yield potential of $2.5-4.9 \mathrm{t} \mathrm{ha}^{-1}$ in research fields under recommended management (Table 1). It is susceptible to scald in the high altitude highlands. Land suitability analysis and mapping results for this variety are presented in Table 10 and Figure 7. Susceptibility of variety Sabini to scald is tolerable since the negative effect on yield and grain quality for malt is negligible according to our unpublished observation during the implementation of USAID-ICARDA seed production and scaling project during 2015-2018. Therefore, its highly suitable land area (307,952 ha) was the third largest after that of IBON174/03 and Grace. 
Table 10. Land area and suitability classes for malt barley variety Sabini production in Ethiopia

\begin{tabular}{|c|c|c|c|c|c|c|c|c|}
\hline \multirow{2}{*}{ Regional states } & \multicolumn{2}{|c|}{ Highly Suitable } & \multicolumn{2}{|c|}{ Moderately Suitable } & \multicolumn{2}{|c|}{ Marginally Suitable } & \multicolumn{2}{|c|}{ Not suitable } \\
\hline & Area (ha) & $\% *$ & Area (ha) & $\% *$ & Area (ha) & $\% *$ & Area (ha) & $\% *$ \\
\hline Amhara & 101,588 & 0.65 & $4,236,844$ & 27.22 & 36,812 & 0.24 & $11,188,125$ & 71.89 \\
\hline Oromia & 185,216 & 0.57 & $8,581,572$ & 26.45 & 71,856 & 0.22 & $23,610,769$ & 72.76 \\
\hline SNNP & 19,840 & 0.18 & $3,450,676$ & 30.56 & 79,660 & 0.71 & $7,739,810$ & 68.55 \\
\hline Tigray & 1,308 & 0.03 & 21,696 & 0.43 & 16 & 0 & $4,997,638$ & 99.54 \\
\hline Afar & 0 & 0 & 0 & 0 & 0 & 0 & $9,562,336$ & 100 \\
\hline BSG & 0 & 0 & 60,236 & 1.2 & 1,596 & 0.03 & $4,938,525$ & 98.76 \\
\hline Gambella & 0 & 0 & 7,308 & 0.28 & 0 & 0 & $2,562,828$ & 99.72 \\
\hline Somali & 0 & 0 & 16 & 0 & 8 & 0 & $31,561,941$ & 100 \\
\hline Total & 307,952 & 0.27 & $16,358,348$ & 14.47 & 189,948 & 0.17 & $96,161,972$ & 85.09 \\
\hline
\end{tabular}

Note. $\mathrm{SNNP}=$ Southern Nations, Nationalities and Peoples; BSG $=$ Benishangul-Gumuz; $* \%$ refers to percent area for each suitability class calculated against the total area for each Regional State.

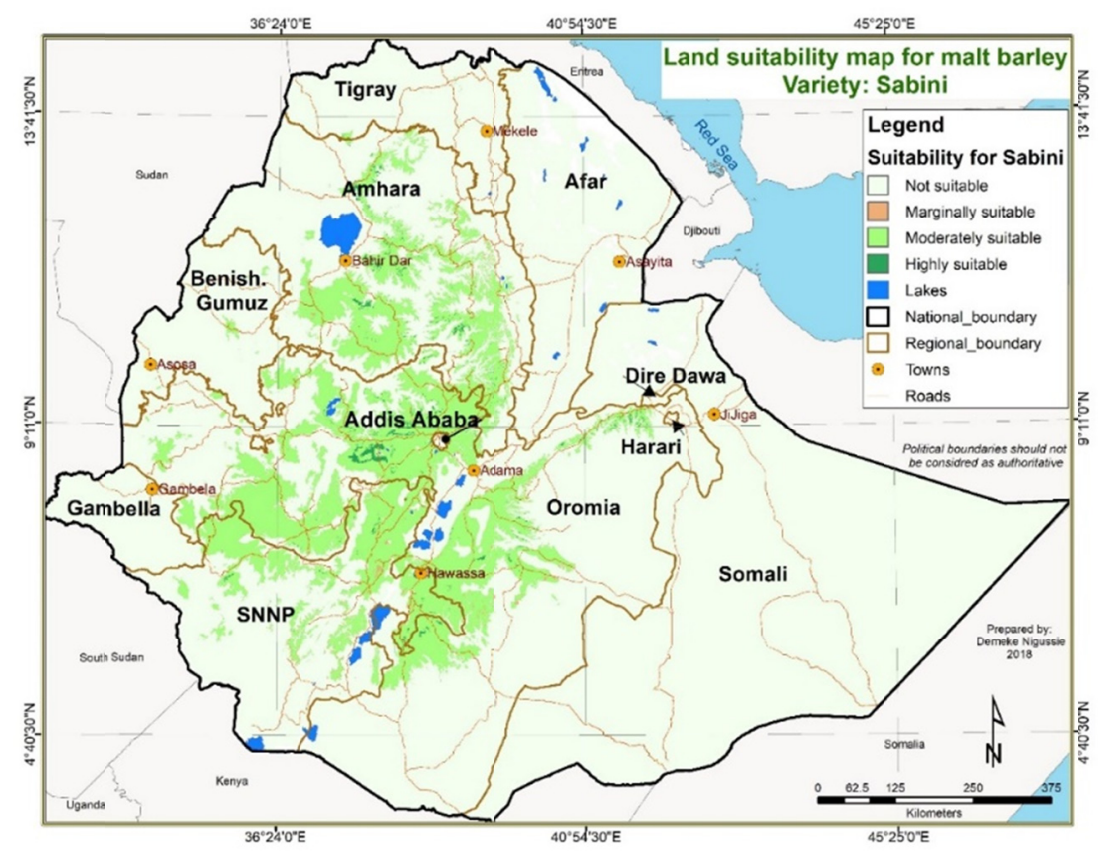

Figure 7. Land suitability map for malt barley variety Sabini

\section{Discussions}

The integrated land suitability analysis on altitude (largely influencing rainfall and temperature which are also major parameters of the analysis), length of growing period, soil type, soil texture, soil drainage, soil $\mathrm{pH}$, soil depth, and slope showed that the size of highly suitable land areas are ranging from 124,004 to125,356 ha for late maturing varieties (Bekoji-1, EH 1847 and Holker) which was by far smaller than that of early maturing varieties (Grace, IBON 174/03 and Sabini) having a range from 307,952 to 1,677,388 ha (Table 4). Physico-chemical grain quality parameters for malt were equally considered with productivity in our integrated land suitability analysis for malt barley production in Ethiopia. With this understanding, the major reasons for differences in size of suitable land share among target varieties are described below.

In Ethiopia, rainfall amount and length of growing period mostly increase with increasing altitude while temperature decreases (Hurni, 1998; MoA, 1998) and, therefore, late-maturing varieties mostly attain their higher productivity in high altitude highlands so long as excessive rainfall and terminal frost are avoided. Our unpublished field observations in high altitude highlands (above 2700 masl) during the implementation of USAID-ICARDA malt barley scaling project during 2015-2018 indicated that late maturing varieties Bekoji-1, EH 1847 and Holker express their higher yield potential when planted as soon as effective rainfall sets in from late May to mid-June in order to have a frost-free period during grain filling in late September to end of October. 
Farmers also prefer these late maturing varieties due to their tall plant height which attributes to higher straw yield to feed livestock and weed suppression effects. Similar to Bekoji-1, EH1847 and Holker, malt barley varieties for the high altitude areas are required to be resistant to scald disease since the infection level of this disease increases with increasing altitude (MoA, 2010, 2011; Aynewa, Dessalegn, \& Bayu, 2013).

Our mapping indicates that land area of altitudes lower than 1500, 1501-2400, and 2401-3200 masl, respectively constitute $65.91,26.37$ and $6.95 \%$ of the land area of Ethiopia with the corresponding annual average temperature of higher than $27.5,20-16$ and $16-11^{\circ} \mathrm{C}$. In comparison to late maturing varieties, early maturing varieties are flexible enough to have larger land area share since they mature early to escape high temperature and rainfall stresses which are limiting malt barley productivity and grain quality. Production of some early maturing varieties may marginally extend up to $3201-3500$ masl covering $0.49 \%$ land share of the country while no production land area above 3500 masl covers $0.29 \%$. Highly suitable land areas for late maturing varieties are in 2600-3000 masl while those of early maturing varieties are in 2000-3000 masl (Table 3). Days to maturity generally increase with increasing altitudes. Higher altitudes with more than 160 days of growing period are difficult for early maturing varieties to harvest and dry unless there are dry spell periods. This extended length of growing period may cause sprouting in the field and spoil grain quality of matured early maturing varieties unless there are mechanized harvesting in a window of dry spells and grain drying facilities. If these facilities are in place, early maturing varieties open an opportunity for double cropping in high altitudes with extra-long growing periods.

Soil acidity which increases with increasing rainfall which in turn largely increases with increasing altitude also limits malt barley productivity and grain quality since availability and toxicity of micronutrients such as aluminum, manganese and iron increases as the $\mathrm{pH}$ decreases. A field experiment elsewhere in southern Ethiopia indicated that barley grain yield productivity of about 1023, 1264, 1772 and $2017 \mathrm{~kg} \mathrm{ha}^{-1}$ on the respective soil $\mathrm{pH}$ of 4.8, 5.2, 5.7 and 6.3 in areas with 2650-2900 masl receiving average annual rainfall of 1000-1300 mm (Boke \& Fekadu, 2019). Again, land share of late maturing varieties which are developed for high altitude highlands of above 2400 masl is limited by the associated lower soil $\mathrm{pH}$. According to the review by Abate, Hussein, Laing, and Mengistu (2016), acid soils with a pH of below 5.5 in the surface layer constitute about $13.2 \%$ of the total land in Ethiopia, which could be $34,931,776$ ha in our mapping. Improving productivity of this acidic land area requires huge investment to meet lime application recommendation of more than $6 \mathrm{t} \mathrm{ha}^{-1}$ for soil with less than $4.5 \mathrm{pH}$; and 4-5 $\mathrm{tha}^{-1}$ for soil with 4.5-5.5 $\mathrm{pH}$ in broadcast application every 5 years though band application reduces the rate by half (Tilahun, Schulz, Warner \& Solomon, 2019). Therefore, to reduce the rate of this huge lime application requirement, breeding to develop acidic soil tolerant malt barley varieties is an important research area in Ethiopia since there is high probability of success as the Brazilian experience shows (Bian et al., 2015).

The latest review by Merga and Ahmed (2019) indicated that Vertisols cover a total area of 12.6 million ha $(10.3 \%)$ of the soils in Ethiopia of which more than $60 \%$ is in the highlands where they are most frequent on the $0-2 \%$ slope range. Because of limited internal drainage, in Ethiopia, the tremendous potential of Vertisols for crop production is severely constrained by waterlogging leading to yield reduction and negatively affecting physical (grain size, plumpness, test weight) and chemical (increasing protein while reducing starch content) quality in malt barley. The highlands cover altitudes of $\geq 1500$ masl having an area of 7,560,000 ha of Vertisols. Intensity of waterlogging increases with increasing altitude since rainfall mostly increases while temperature decreases with increasing altitudes. Review of worldwide experiences show that barley is more susceptible to waterlogging stress than other cereals, and waterlogging in general and on Vertisols in particular is a major limiting factor for barley production (Bertholdsson, 2013). Therefore, having such large area of land in the Ethiopian highlands, Vertisols are marginally suitable for barley production in general and for malt barley in particular since malt barley, as compared to food barley, grows slowly at early stage and waterlogging stresses spoil grain quality. However, worldwide experiences in breeding for waterlogging tolerance (Bertholdsson, 2013) and the available diversity of barley in the Ethiopian highlands (Hadado, Rau, Bitocchi, \& Papa, 2010) are important inputs to start the breeding program at least to reclaim this vast resource for seed production where chemical grain quality of malt barley is not a priority.

Soil depth and slope are interrelated parameters which all together affect soil water holding capacity thereby length of growing period of malt barley. Generally, soil depth decreases while slope (because of ruggedness of the highlands) increases with increasing altitude because of increasing soil erosion associated with increasing rainfall and ruggedness. Because of these scenarios, soil erosion, which significantly reduces soil depth, is a serious soil degradation factor in the highlands of Ethiopia where the recent study reported soil losses of 0 in plain areas to $237 \mathrm{t} \mathrm{ha}^{-1}$ year $^{-1}$ in the steep slopes (Gashaw, Tulu, \& Argaw, 2017). Because of direct physical soil 
loss by erosion on higher slopes in the highlands of Ethiopia, soil clay, $\mathrm{pH}$, cation exchange capacity, exchangeable $\mathrm{Ca}, \mathrm{Mg}$, extractable $\mathrm{Mn}, \mathrm{Zn}, \mathrm{Fe}$, and $\mathrm{Cu}$ generally showed a decreasing trend with increasing slope gradient (Jembere, Mamo, \& Kibret, 2017). Estimates through modeling work also suggests that soil erosion in Ethiopia reduces the potential production of the land by $10 \%$ in 2010 and by $30 \%$ in 2030 . As a result, the value added per capita per annum in the agricultural sector will go down from US\$372 in 2010 to US\$162 in 2030 (Gashaw et al., 2017, citing Sonneveld \& Keyzer, 2003). This is again additional huge challenge for Ethiopia to improve productivity and production of crops in general and malt barley in particular as it needs highly suitable land areas for maintaining both productivity and grain quality for breweries.

Therefore, our integrated multi-layer land suitability analysis and mapping show that early maturing malt barley varieties have larger highly and moderately suitable land area shares as compared to the late maturing varieties which have narrow niche, usually in high altitude highlands. Moderately suitable land areas may need additional interventions on top of the recommended production packages of malt barley production. According to the recent report on the results of nationwide soil and water conservation measures which have been going on for decades in the rugged highlands resulted in significant improvements in the agronomic and economic efficiency of productivity enhancing technologies (Biru, Zeller, \& Loos, 2020).

In the final analysis, this work is a national level and broad scale integrated multi-criteria land suitability analysis without considering irrigation potentials and socio-economic aspects. Amhara, Oromia, SNNP and Tigray Regional States remain the major regions with suitable land areas for production of available varieties of malt barley compared to Afar, Benishangul Gumuz, Gambella, and Somali Regional States. Oromia Regional State has more highly suitable and moderately suitable land areas than other regional states. However, the highly suitable land areas are limited compared to moderately suitable ones, which are higher across the regional states. For the malt barley varieties considered in this analysis, the highly suitable land areas were found to be much smaller than the current estimated area under barley production in the country and crop level suitability except for one variety. IBON 174/03 has the highest overall highly suitable area of 1.7 million ha which is close to the crop suitability level followed by Grace with 0.8 million ha and Sabini with 0.3 million ha. Oromia Regional State has the highest moderately suitable land area for malt barley of which Grace, Sabini and IBON 174/03 has a share of up to $35.02 \%, 26.45 \%$ and $18.82 \%$, respectively.

\section{Conclusions and Recommendations}

\subsection{Conclusions}

Although this work is a broad scale nationwide integrated multi-criteria suitability analysis, which is only based on biophysical factors, it is intended to serve as a guide for agricultural research and development related policy and decision-making at broad scale (national level). The analysis clearly showed that, as compared to late maturing malt barley varieties, early maturing ones have larger niches of highly and moderately suitable land areas and should receive more attention to improve productivity and production of malt barley in the highlands of Ethiopia. In addition to identifying and mapping different land suitability classes for malt barley production in Ethiopia, we have also shown priority research and development areas to improve productivity of acidic and waterlogging soils as well as soil and water conservation works to improve natural resource base potential for enhancing agronomic and economically efficient responses to application of improved crop technologies.

\subsection{Recommendations}

It is recommended to undertake site-specific analysis and to map the key parameters at higher spatial details to better understand the granularity and level of scaling-up of the specific crop technology for targeting location specific recommendation at farm to farming systems level. Data on performance of crop varieties across a wide range of representative environments are very scanty and need future attention. The organizations that are involved in improving soil, land use/land cover, and climate information at national level need to produce high-resolution and reliable information that could be used for site-specific spatial and simulation modelling for agricultural application. Furthermore, researchers involved in crop improvements also need to be able to use these suitability analysis results as a general guide in their research targeting decisions and feedback on performance of the crops for further refinement. However, farmers know their farm plots and therefore we can use their knowledge for avoiding shallow depth soils, frost frequented landforms and unproductive soils to make our results applicable at farm level. Therefore, the integrated multi-criteria suitability analysis results suggest that currently available improved malt barley varieties can be targeted for scaling out in the identified land suitability classes in the highlands of Ethiopia.

It is also suggested that researchers need to develop, update and have detailed documents elaborating information on environmental requirements for the different crops and varieties for suitability analysis, mapping and 
simulation modelling based on recent research findings, particularly when new varieties are released. We also recommend leveraging recent advances in Earth Observation, Bigdata and ICTs for demand-driven decision support system for targeting site-specific intervention and smart farming for building resilient agroecosystems.

Currently available breeding technologies, experiences elsewhere and the high barley diversity we have in the highlands of Ethiopia suggest that breeding for developing early maturing, acidic soil and waterlogging tolerant malt barley varieties are important research areas which should receive attention.

\section{References}

Abate, E., Hussein, S., Laing, M., \& Mengistu, F. (2016). Soil acidity under multiple land-uses: assessment of perceived causes and indicators, and nutrient dynamics in small-holders' mixed-farming system of northwest Ethiopia. Soil \& Plant Science, 67(2), 134-147. https://doi.org/10.1080/09064710.2016.1230227

Ajith, A. (2009). Genotype effect of South African barley cultivars on malting quality under different nitrogen levels (Unpublished MSc thesis, University of the Free State, Bloemfontein).

Aynewa, Y., Dessalegn, T., \& Bayu, W. (2013). Participatory evaluation of malt barley genotypes (Hordeum vulgare L.) genotypes for yield and other agronomic traits at northwest Ethiopia. Wudpecker Journal of Agricultural Research, 2(8), 218-222.

Bertholdsson, N. (2013). Screening for barley waterlogging tolerance in Nordic barley cultivars (Hordeum vulgare L.) using chlorophyll fluorescence on hydroponically grown plants. Agronomy, 3, 376-390. https://doi.org/10.3390/agronomy3020376

Bian, M., Jin, X., Broughton, S., Zhang, X., Zhou, G., Zhou, M., ... Li, C. (2015). A new allele of acid soil tolerance gene from a malting barley variety. BMC Genetics, 16, 92. https://doi.org/10.1186/ s12863-015-0254-4

Biru, W. D., Zeller, M., \& Loos, T. K. (2020). The impact of agricultural technologies on poverty and vulnerability of smallholders in Ethiopia: A panel data analysis. Social Indicators Research, 147, 517-544. https://doi.org/10.1007/s11205-019-02166-0

Boke, S., \& Fekadu, A. (2019). Lime and NPK effect on soil acidity and yield of barley in different acid soils of southern region. Journal of Natural Sciences Research, 2(7), 113-122. https://doi.org/10.7176/JNSR/ 9-14-01

CSA (Central Statistical Agency). (2017). Report on area and production of major crops by private peasant holdings in 2016/2017 meher season. CSA, Addis Ababa, Ethiopia.

EIAR (Ethiopian Institute of Agricultural Research). (2015). Malt barley research and achievements. Retrieved from https://www.facebook.com/EIARPR/posts/432653976888664:0

Elsheikh, F., \& Abdalla, R. (2016). Physical land suitability assessment based on FAO framework. IOSR Journal of Engineering, 12(6), 36-44.

FAO (Food and Agriculture Organization). (1976). Framework for land evaluation. FAO, Rome, Italy.

FAO (Food and Agriculture Organization). (1984). Land evaluation: Part three. FAO/MoA, Addis Ababa, Ethiopia.

FAO (Food and Agriculture Organization). (1993). Guidelines for land use planning. FAO Development Series 1. FAO, Rome, Italy.

FAO (Food and Agriculture Organization). (2011). Ethiopia country programming framework 2012-2015. Office of the FAO Representative in Ethiopia to AU and ECA, Addis Ababa, Ethiopia.

FAO (Food and Agriculture Organization). (2014). Food balance sheets. Rome, Italy: FAOSTAT. Retrieved from http://faostat3.fao.org/download/FB/FBS/E

FAO (Food and Agriculture Organization). (2016). AQUASTAT country profile-Ethiopia. FAO, Rome, Italy.

Fazzini, M., Bisci, C., \& Billi, P. (2015). The climate of Ethiopia. In P. Billi (Ed.), Landscapes and landforms of Ethiopia. World Geomorphological Landscapes. https://doi.org/10.1007/978-94-017-8026-1_3

Gashaw, T., Tulu, T., \& Argaw, M. (2017). Erosion risk assessment for prioritization of conservation measures in Geleda watershed, Blue Nile basin, Ethiopia. Environ Syst Res, 6(1). https://doi.org/10.1186/s40068016-0078-x 
Gessesse, A. S. (2017). Ethiopia to end malt import: Boosting local production. Retrieved from https://newbusi nessethiopia.com/ethiopia-to-end-malt-import-boosting-local-production

Girma, F., Getahun, K., \& Babu, A. (2019). Assessment of Physical Land Suitability for Surface Irrigation by using GIS and RS, In case of Loma District, South Western Ethiopia. Int. J. Curr. Res. Aca. Rev., 7(1), 32-45. https://doi.org/10.20546/ijcrar.2019.701.004

Hadado, T. T., Rau, D., Bitocchi, E., \& Papa, R. (2010). Adaptation and diversity along an altitudinal gradient in Ethiopian barley (Hordeum vulgare L.) landraces revealed by molecular analysis. BMC Plant Biology, 10(121), 1-20. https://doi.org/10.1186/1471-2229-10-121

Hurni, H. (1998). Agro-ecological belts of Ethiopia. University of Bern, Switzerland; Ministry of Agriculture, Addis Ababa, Ethiopia.

ISRIC (International Soil Reference Information Center). (2015). Retrieved February 7, 2016, from http://www.soilgrids.org

Jarvis, A., Reuter, H. I., Nelson, A., \& Guevara, E. (2008). Hole-filled SRTM for the Globe Version 4 (CGIAR-CSI SRTM 90m Database). Retrieved from http://srtm.csi.cgiar.org

Jembere, K., Mamo, M., \& Kibret, K. (2017). Characteristics of agricultural landscape features and local soil fertility management practices in northwestern Amhara, Ethiopia. J. Agron., 16(4), 180-195. https://doi.org/ 10.3923/ja.2017.180.195

Kassie, B. T. (2014). Climate variability and change in Ethiopia: Exploring impacts and adaptation options for cereal production (Unpublished $\mathrm{PhD}$ thesis, Wageningen University, Wageningen).

Lakew, B., Yigezu, Y., Yirga, C., \& Aw-Hassan, A. A. (2015). Current situation, investment opportunities, and future outlooks of malt barley production in Ethiopia. Retrieved from https://hdl.handle.net/20.500. $11766 / 4918$

Löw, F., Biradar, C., Dubovyk, O., Fliemann, E., Akramkhanov, A., Vallejo, A. N., \& Waldner, F. (2018). Regional-scale monitoring of cropland intensity and productivity with multi-source satellite image time series. GIScience \& Remote Sensing, 55(4), 539-567. https://doi.org/10.1080/15481603.2017.1414010

Mehari, M., Alamerew, S., \& Lakew, B. (2015). Genotype by environment interaction for protein content of malt barley genotypes using the additive main effect and multiplicative interaction effect model (AMMI) and genotype plus genotype by environment interaction (GGE) biplot. Asian Journal of Agricultural Research, 9(6), 305-14. https://doi.org/10.3923/ajar.2015.305.314

Mekonnen, B. (2013). The malt effect: How the growing beer industry creates opportunities for barley farmers. Retrieved from http://eco-opia.org/2013/11/22/the-malt-effect-how-the-growing-beer-industry-creates-oppo rtunities-for-barleyfarmers

Merga, B., \& Ahmed, A. (2019). A review on agricultural problems and their management in Ethiopia. Turkish Journal of Agriculture Food Science and Technology, 7(8), 1189-1202. https://doi.org/10.24925/turjaf.v7i8. $1189-1202.2626$

MoA (Ministry of Agriculture). (1998). Agroecological zones of Ethiopia. MoA, Addis Ababa, Ethiopia.

MoA (Ministry of Agriculture). (2010). Crop variety register (Issue No. 13). MoA, Addis Ababa, Ethiopia.

MoA (Ministry of Agriculture). (2011). Crop variety register (Issue No. 14). MoA, Addis Ababa, Ethiopia.

MoA (Ministry of Agriculture). (2012). Crop variety register (Issue No. 15). MoA, Addis Ababa, Ethiopia.

MoARD (Ministry of Agriculture and Rural Development). (2013). Crop variety register (Issue No. 16). MoARD, Addis Ababa, Ethiopia.

Muhe, K. (2011). Opportunities and challenges in malt barley research and production in North Shewa of the Amhara Region. In B. Mulatu \& S. Grando (Eds.), Barley research and development in Ethiopia (pp. 73-76). Aleppo, Syria: ICARDA.

Nigussie, D., Tibebe, D., \& Demelash, M. (2018). GIS-based land suitability mapping for selected cereal and oil crops for technology targeting and scaling-up. In D. Tibebe, G. Mamo, F. Getachew, \& K. Abera (Eds.), Results of climate, geospatial, and biometrics research. EIAR, Addis Ababa, Ethiopia.

NSIA (National Seed Industry Agency). (1998). Crop Variety Register (Issue No. 1). NSIA, Addis Ababa, Ethiopia. 
Perveen, M. F., Nagasawa, R., Uddin, M. I., \& Delowar, H. K. M. (2007). Crop-land suitability analysis using a multi-criteria evaluation and GIS approach. University of California, Berkeley, USA.

Pettapiece, W. W. (1995). Land suitability rating system for agricultural crops: 1. Spring-seeded small grains (Tech. Bull. 1995-6E). Centre for Land and Biological Resources Research, Agriculture and Agri-Food, Ottawa, Canada.

Rabia, A. H. (2012). A GIS based land suitability assessment for agricultural planning in Kilte Awulaelo district, Ethiopia. The 4th International Congress of ECSSS, EUROSOIL 2012 "Soil Science for the Benefit of Mankind and Environment", June 2-6, 2012, Bari, Italy. Retrieved from https://www.researchgate.net/ publication/229071904

Radcliffe, D. J., \& Bechtold, G. K. (1989). Land evaluation of Haykoch and Butajira Awraja (Shewa). UNDP/FAO, Addis Ababa, Ethiopia. Retrieved from http://www.fao.org/3/as000e/as000e.pdf

Rashid, S., Abate, G. T., Lemma, S., Warner, J., Kasa, L., \& Minot, N. (2015). The barley value chain in Ethiopia. REAP/IFPRI, Addis Abeba, Ethiopia.

Saaty, R. W. (1987). The analytic hierarchy process: What it is and how it is used. Mathematical Modelling, 9(3-5), 161-176. https://doi.org/10.1016/0270-0255(87)90473-8

Selassie, Y. G., Ayalew, G., Elias, E., \& Getahun, M. (2014). Soil characterization and land suitability evaluation to cereal crops in Yigossa watershed, northwestern Ethiopia. Journal of Agricultural Science, 6(5), 199-206. https://doi.org/10.5539/jas.v6n5p199

Singha, C., \& Swai, K. C. (2016). Land suitability evaluation criteria for agricultural crop selection: A review. Agricultural Reviews, 37(2), 125-132. https://doi.org/10.18805/ar.v37i2.10737

Sys, C., Ranst, V., Debaveye, J., \& Beernaert, F. (1993). Land evaluation part III: Crop requirements. Agricultural Publication No. 7, Brussels, Belgium.

Tilahun, A., Schulz, S., Warner, J., \& Solomon, T. (2019). Managing acid soils for reclaiming livelihoods in Ethiopia. ICRISAT-GIZ, Addis Ababa, Ethiopia.

WBISPP (Woody Biomass Inventory and Strategic Planning Project). (2004). Woody biomass inventory and strategic planning project database. MoA, Addis Ababa, Ethiopia.

Yitbarek, T., Kibret, K., Gebrekidan, H., \& Beyene, S. (2013). Physical land suitability evaluation for rainfed production of cotton, maize, upland rice and sorghum in Abobo area, western Ethiopia. American Journal of Research Communication, 1(10), 296-318.

Yohannes, H., \& Soromessa, T. (2018) Land suitability assessment for major crops by using GIS-based multi-criteria approach in Andit Tid watershed, Ethiopia. Cogent. Food and Agriculture, 4(1), 1470481. https://doi.org/10.1080/23311932.2018.1470481

\section{Copyrights}

Copyright for this article is retained by the author(s), with first publication rights granted to the journal.

This is an open-access article distributed under the terms and conditions of the Creative Commons Attribution license (http://creativecommons.org/licenses/by/4.0/). 